\title{
MOLD PROPERTIES OF INDONESIA NATURE SAND AS GREEN SAND
}

\author{
Yusup Hendronursito, Muhammad Amin, Kusno Isnugroho, David C B \\ Research Unit For Mineral Technology - Indonesian Institute of Sciences \\ Jl. Ir. Sutami Km. 15 Tanjung Bintang, South Lampung - Indonesia \\ e-mail: yusu016@lipi.go.id
}

\begin{abstract}
The mould properties of Juwono sand, were investigated. The samples were subjected to various physical and mechanical test. These include permeability, green compression strength, and chemical composition by $\mathrm{XRF/} \mathrm{XRD} \mathrm{analysis.} \mathrm{Green} \mathrm{shear} \mathrm{strength,} \mathrm{grain} \mathrm{shape,} \mathrm{water} \mathrm{content,} \mathrm{and}$ clay content were also carried out on the samples. Juwono sand casting containing $32.76 \%$ clay and category in grade $212 / 75$ of fine sub grades were found to posses adequate permeability, good strength and refractoriness suitable for casting of both ferrous and non ferrous alloys.
\end{abstract}

Key Words : sand, physiscal test, mechanical test, refractoriness, casting.

\begin{abstract}
Abstrak
Telah dilakukan pengujian fisik dan mekanikal terhadap pasir cetak yang berasal dari pasir alam Juwono, Pati, Jawa Tengah - Indonesia. Pengujian meliputi permeabilitas, kuat tekan basah, kuat geser basah, komposisi kimia menggunakan $X$-ray fluorescence dan $X$-ray diffraction, bentuk butir, kadar air, dan kadar tanah liat. Hasil pengujian menunjukkan bahwa pasir alam Juwono termasuk kedalam grade 212/75 yang memiliki nilai permeabilitas yang memadai, kekuaatan dan sifat tahan api yang baik sesuai untuk pengecoran ferrous and non ferrous alloy serta sifat mampu bentuk yang dipengaruhi oleh kadar tanah liat yang sangat tinggi yaitu $32,76 \%$.
\end{abstract}

Kata kunci : pengujian fisik dan mekanikal, pasir cetak, pengecoran

Diterima (received ) : 18 Januari 2018 , Direvisi (revised ) : 04 Maret 2019

Disetujui (accepted) : 12 Maret 2019

\section{INTRODUCTION}

The nature sand from Juwono, Pati, Central Java - Indonesia were investigated. Juwono sand usually applicated for a nonferrous foundry. Juwono sand type of natural sand that easily applied to use and economical because can reusable. In the application for sand casting, this nature sand only added \pm $8 \%$ of water without adding additive materials like bentonite. Juwono sand more easily formed and the surface of molds more smooth than others sand. Data on materials properties of Juwono sand not yet available ${ }^{1)}$, so needs to characterization this sand like a sand mold to be a reference for artificial sand mold. Mihira (1998) on her paper explained that many of foundry in Indonesia manually controlled to molding sand properties without testing equipment. This caused industrial foundry in
Indonesia weak technology2). Molding is an important aspect of foundry operation, the soundness or otherwise of casting depends on the natural sand properties of the initial molding material used ${ }^{3}$. The cost of casting also depends on the availability of molding materials.

An investigation has been carried out on some of the natural sand deposits across the country. In some of the earlier works, Sulistyani et al. (2015) investigated the molding properties of Merapi volcanic and its potential application ${ }^{4}$. Puspitasari et al. (2016), investigated Gunung Kelud eruption sand for Al-Si casting. In this research used some binder variation and then tested of strength test, quality, dan fluidity5). Yusup and Yogi (2016), studied on Lampung Province local sand for Aluminium scrap casting application $^{6)}$. 


\section{MATERIALS AND METHODS}

The major materials for this work are nature sand. Sand was collected from Juwono - Pati, center of Java - Indonesia. The sample tested include Grain fine number (GFN), Permeability, green strength test, green shear test, clay content, and chemical analysis.

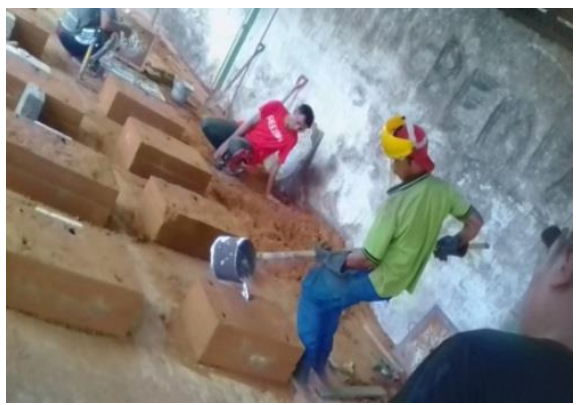

Figure 1.

Juwono Nature Sand for SMEs Foundry

The sample was mounted into the permeability machine and $2000 \mathrm{~cm}^{3}$ of air was passed through the prepared sample and the time taken by it to completely pass through the sand sample was noted. The instrument used is presented in formula $1^{7)}$. The permeability number was calculated using the formula:

$P=(V \times H) /(p \times A \times T)$

where $\mathrm{V}$ is the volume of air $\left(2000 \mathrm{~cm}^{3}\right), \mathrm{H}$ is the height of sand specimen $(5 \mathrm{~cm}), p$ is air pressure in $\mathrm{cm}$ of water $(9.8 \mathrm{~cm}), \mathrm{A}$ is crosssectional area of the sand specimen (19.63 $\mathrm{cm}^{2}$ ), $\mathrm{T}$ is the time in minutes for the complete air to pass through.

The green compression test was carried out by applying the load of $25 \mathrm{kN}$ on the strength testing machine and increasing it gradually on each sample. The samples were tested for three times. This tested was done until a crack appeared on the sample. The average for three samples was found and recorded. In green shear strength test, the sample putting on the loading position of the universal sand strength-testing machine. Load of $25 \mathrm{~g} / \mathrm{cm}^{2}$ was applied until a crack appeared on the sample. Three samples were used for the test and the average value for the green strength was recorded.

Table 1.

Permeabiliy, Green Compression Strength And Shear Strength Test Result

\begin{tabular}{cccccc}
\hline \multirow{2}{*}{ No. } & \multicolumn{1}{c}{ Type of testing } & \multicolumn{4}{c}{ Test result } \\
\cline { 3 - 6 } & & Sample 1 & Sample 2 & Sample 3 & Average \\
\hline 1. & Weigh of sample (gram) & 165.00 & 165.00 & 165.00 & 165.00 \\
2. & Permeability $(\mathrm{ml} / \mathrm{min})$ & 60 & 60 & 62 & 60.67 \\
3. & Green Compression Strength $\left(\mathrm{kN} / \mathrm{m}^{2}\right)$ & 95.50 & 91.30 & 95.00 & 93.93 \\
4. & Green Shear Strength $\left(\mathrm{kN} / \mathrm{m}^{2}\right)$ & 75.00 & 71.90 & 74.80 & 73.90 \\
\hline
\end{tabular}

The average of three samples for Permeability, Green compression strength, and shear strength test results in Table 1 showed the value of permeability 60.67 has fulfilled the minimal standard of sand casting in foundry used with nominal standard about 20 $-120 \mathrm{ml} / \mathrm{min}^{8}$. While the green compression strength and green shear strength value about 93.93 and $73.9 \mathrm{kN} / \mathrm{m}^{2}$ respectively.

The investigation of the shape of grain has been done by an optical microscope with $100 x$ in scale from washed sample and meshing. The shape of sand grain of Juwono sands shown in Figure 2 showed there are tapered corners but not in all side, subrounded category.

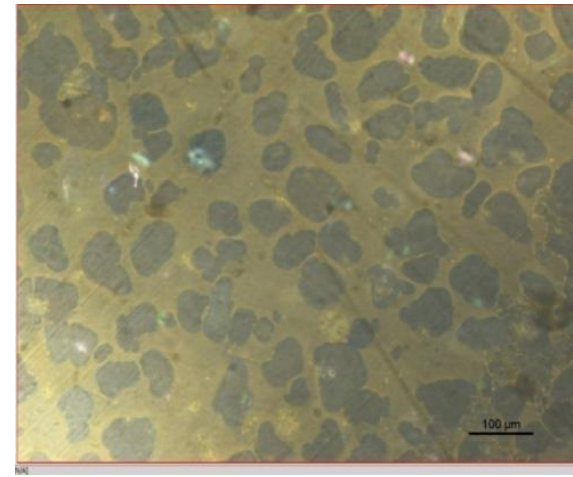

Figure 2.

Shape Of Juwono Sands

The result of GFN (Table 2) showed the Grain Fineness Number (GFN) was 202.15 with the largest grain distribution in 200 mesh $(61.38 \%)$ and $<200$ mesh (17.28\%). 
Table 2.

GFN Test Result

\begin{tabular}{ccccccc}
\hline No. & micron & Mesh & $\begin{array}{c}\text { weigh } \\
\text { (gr) }\end{array}$ & Percent & Sn & Wn.Sn \\
\hline 1. & & $<20$ & 0 & 0 & 9.6 & 0 \\
2. & 841 & 20 & 0 & 0 & 17.95 & 0 \\
3. & 420 & 40 & 0.4 & 0.44 & 40 & 16 \\
4. & 250 & 60 & 0.35 & 0.39 & 57.45 & 20.1075 \\
5. & 177 & 80 & 9.92 & 11.1 & 82 & 813.44 \\
6. & 149 & 100 & 8.41 & 9.41 & 100 & 841 \\
7. & 74 & 200 & 54.89 & 61.38 & 200 & 10978 \\
8. & \multicolumn{7}{c}{ pan } & 15.45 & 17.28 & 350 & 5407.5 \\
& \multicolumn{7}{c}{ GFN } & & & 202.15 \\
\hline
\end{tabular}

Moisture content $50 \mathrm{~g}$ of the sand sample was measured using digital balance and dried at the temperature of $105^{\circ} \mathrm{C}-110^{\circ} \mathrm{C}$ for 2 hours to evaporate all the moisture in the sand. The sample was then weighed. The weight difference between the initial and new weight was expressed in percentage to give the moisture content of the sand. Clay Content The dried sample from the moisture content determination was washed four times till the surface was clean. It was then dried again and weighed. The difference between the weight of the washed and its initial weight expressed in percentage was taken as the clay content.

$$
\begin{aligned}
& \text { Moisture content }(\%)= \\
& \frac{\text { Initial weigh-final weigh }}{\text { Initial weigh }} \times 100 \%
\end{aligned}
$$

Clay content $(\%)=$

$\frac{\text { Initial weigh-weigh after wash }}{\text { Initial weigh }} \times 100 \%$
Table 3.

Moisture and Clay content test result

\begin{tabular}{cc}
\hline $\begin{array}{c}\text { Moisture } \\
\text { content (\%) }\end{array}$ & $\begin{array}{c}\text { Clay content } \\
(\%)\end{array}$ \\
\hline 6.78 & 32.76 \\
\hline
\end{tabular}

X-Ray Fluorescence (XRF) and X-Ray Powder Diffraction (XRD) tests were conducted using Phillips PW $2400 \quad X$-ray Spectrometer and X-pert MPD model PW 3040 Phillips respectively to analyze the elemental composition and phase. The silica content of Juwono sand casting $29.414 \%$, less than others silica sand about $55.3-99.87 \%$. The other chemical compositions are $\mathrm{Fe}$ and $\mathrm{Al}$, $10.914 \%$ and $9.728 \%$ of weighing respectively. The metal elements such as Ti, Zn, Zr, Cr, Sr, $S n$ existed with the very small percentage that was less than $1 \%$. While the results of the XRD analysis showed that mineral content was quartz, hematite, periclase and eliminate.

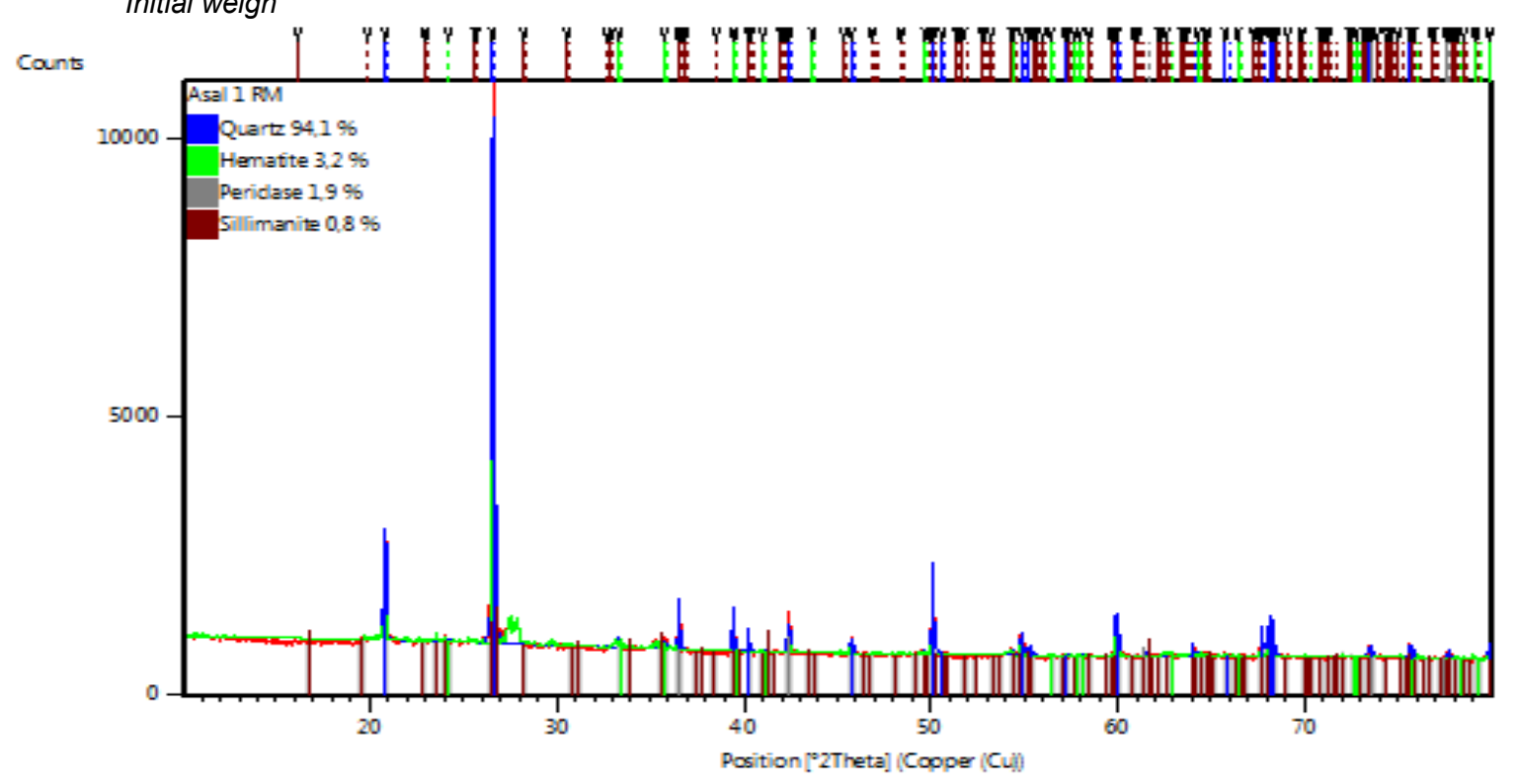

Figure 3.

XRD Analysis Result 
Table 4.

XRF Analysis Result

\begin{tabular}{cccccccc}
\hline Compound & Conc & Unit & & Compound & Conc & Unit \\
\cline { 1 - 3 } \cline { 5 - 7 } $\mathrm{Mg}$ & 0.609 & $\%$ & & $\mathrm{Zn}$ & 0.112 & $\%$ \\
$\mathrm{Al}$ & 9.728 & $\%$ & & $\mathrm{Ga}$ & 35.3 & $\mathrm{ppm}$ \\
$\mathrm{Si}$ & 29.418 & $\%$ & & $\mathrm{As}$ & 173.2 & $\mathrm{ppm}$ \\
$\mathrm{P}$ & 358.2 & $\mathrm{ppm}$ & & $\mathrm{Kr}$ & 0.52 & $\%$ \\
$\mathrm{~S}$ & 710.2 & $\mathrm{ppm}$ & & $\mathrm{Rb}$ & 131.3 & $\mathrm{ppm}$ \\
$\mathrm{Cl}$ & 314.6 & $\mathrm{ppm}$ & & $\mathrm{Sr}$ & 244 & $\mathrm{ppm}$ \\
$\mathrm{K}$ & 1.948 & $\%$ & & $\mathrm{Y}$ & 63.3 & $\mathrm{ppm}$ \\
$\mathrm{Ca}$ & 2.971 & $\%$ & & $\mathrm{Zr}$ & 870.9 & $\mathrm{ppm}$ \\
$\mathrm{Ti}$ & 0.703 & $\%$ & & $\mathrm{Nb}$ & 37.2 & $\mathrm{ppm}$ \\
$\mathrm{V}$ & 216.8 & $\mathrm{ppm}$ & & $\mathrm{Ag}$ & 0.16 & $\%$ \\
$\mathrm{Cr}$ & 201 & $\mathrm{ppm}$ & & $\mathrm{Sn}$ & 56.9 & $\mathrm{ppm}$ \\
$\mathrm{Mn}$ & 0.137 & $\%$ & & $\mathrm{Te}$ & 89.2 & $\mathrm{ppm}$ \\
$\mathrm{Fe}$ & 10.914 & $\%$ & & $\mathrm{Ba}$ & 337.3 & $\mathrm{ppm}$ \\
$\mathrm{Co}$ & 519.2 & $\mathrm{ppm}$ & & & & \\
$\mathrm{Ni}$ & 93.7 & $\mathrm{ppm}$ & & & & \\
\hline
\end{tabular}

\section{RESULTS AND DISCUSSION}

The result of the material properties of Juwono sand presented in Tabel 1 until Table
3. While the mineralogical composition analysis presented in Table 4, Figure 4, and Figure 3 . The summary of these result showed in Table 5.

Table 5.

Resume The Analysis Result

\begin{tabular}{|c|c|c|c|c|c|}
\hline \multirow[b]{3}{*}{ Permeability (ml/min) } & \multirow[t]{2}{*}{ Standard } & \multirow[t]{2}{*}{ Result } & \multicolumn{3}{|c|}{$\begin{array}{l}\text { Other sand (based on personal } \\
\text { data) }\end{array}$} \\
\hline & & & $\begin{array}{l}\text { Tanjung } \\
\text { Bintang }\end{array}$ & Maringgai & Ceper \\
\hline & $20-120^{7)}$ & 60.67 & 266.67 & & \\
\hline $\begin{array}{l}\text { Green compression } \\
\text { strength }\left(\mathrm{kN} / \mathrm{m}^{2}\right)\end{array}$ & $51.33-103.14^{9)}$ & 93.93 & & & \\
\hline \multirow[t]{2}{*}{ GFN } & $\begin{array}{l}10-220^{11)} \text { sand } \\
\text { casting }\end{array}$ & 220.15 & 48.5 & 47.6 & 31.3 \\
\hline & $\begin{array}{l}35-140^{10)} \text { for cast } \\
\text { product }\end{array}$ & & & & \\
\hline Clay Content (\%) & $10-20^{11)}$ & 32.76 & 3.03 & 8.12 & 35.37 \\
\hline Water content (\%) & $2-12^{12)}$ & 6.78 & 0.135 & 0.28 & 1.16 \\
\hline
\end{tabular}

Table 1. represented that permeability test result of Juwono sand approximately $60.67 \mathrm{ml} / \mathrm{min}$, lower than Tanjung Bintang, Lampung Province - Indonesia local sand approximately 266.676), but this value has fulfilled the minimal requirement value as molding sand approximately $20-120 \mathrm{ml} / \mathrm{min}^{7}$. The compressive strength test result indicated that value $93.93 \mathrm{kN} / \mathrm{m}^{2}$ has fulfilled the minimal requirment value of approximately 51.33
$\mathrm{kN} / \mathrm{m}^{2}$ - $103.14 \mathrm{kN} / \mathrm{m}^{2}$ 9). The lowes permeability of Juwono sand while the green compresive strength is high caused by the shape of sand which is sub-rounded. This angled of sand will make increasingly strong of particle but formed porosity that cause decreasing the airflow at permeability test.

Grain fine number of Juwono sand more high than other local sand, according to Rao, P. N. (2001) GFN average for sand casting 
approximately $35-140$ and grouped according to the type and size of cast product ${ }^{10)}$, while according to R. L Agarwal et.al, GFN value for sand casting about $10-220$. Based on clay content and water content approximately $10-20 \%$ and $2-$ $12 \%$ respectively ${ }^{11,12)}$, clay content of Juwono sand is higher and effect to essay formed without added with an additive as a binder. This characteristic of Juwono sand also causes higher green compressive strength about $70-90 \mathrm{kN} / \mathrm{m}^{2}$. This is because the clay content increased more fine clay particles occupy the available spaces between the sand grains. Compared to another sand characteristic, the sand from Juwono has a higher clay content compared to Tanjung Bintang and Maringgai sand but has a clay content that is almost the same as Klaten sand with a higher water content compared to other sands. Juwono sand casting chemical composition content of iron oxide $\left(\mathrm{Fe}_{2} \mathrm{O}_{3}\right)$ in the form of the red iron oxide or more commonly known as hematite. Iron oxides have been used for years in foundry applications to improve core properties and the quality of castings. Iron oxides have proven to be advantageous as an additive to foundry sand molding aggregates, which in turn improves the quality of castings, by reducing the formation of thermal expansion defects, such as veining, scabs, buckles, and rat tails as well as gas defects, such as pinholes and metal penetration ${ }^{12)}$. Red iron oxide typically includes $60-87 \% \quad \mathrm{FezO} 3, \quad 7.5-8.5 \%$ silica dioxide (SiOz), 2-9.5\% alumina dioxide (A101), $0.1-11 \%$ calcium oxide $(\mathrm{CaO}), 0.2-$ $2.6 \%$ magnesium oxide $(\mathrm{MgO})$ and $0.2-0.4 \%$ manganese oxide $(\mathrm{MnO})^{12)}$. While periclase often called magnesium oxide whit chemical formulation of $\mathrm{MgO}$. Magnesium oxide effected on refractories of sand casting. Pure $\mathrm{MgO}$ has a high melting point, good refractory properties, and well resistant to attack by basic environments often found in the steel making process ${ }^{13)}$. The siliminate common form of aluminum silicate $\left(\mathrm{Al}_{2} \mathrm{SiO}_{5}\right)$. All break down of aluminum silicates at high temperatures to form mullite and silica. Therefore, aluminum silicate $\left(\mathrm{Al}_{2} \mathrm{SiO}_{5}\right)$ for foundry use are produced by calcining these minerals. Depending on the sintering cycle, the silica may be present as cristobalite or as amorphous silica. The grains are highly angular. These materials have high refractoriness, low thermal expansion, and high resistance to thermal shock. They are widely used in precision investment foundries, often in combination with zircon ${ }^{13)}$.

\section{CONCLUSIONS}

The GFN test result showed the maximal distribution in mesh 80 until under mesh 200 with $61.38 \%$ of weigh in mesh 200 , based on GFN test result compared with Sub Grades Table for sand, Juwono sand included in grade $212 / 75$. Natural molding sands from Juwono possess high flexibility of operation. Unlike the synthetic sands, here accurate adjustment of moisture is not required and the range of permissible moisture is high. These sands are therefore suitable for molding. The quantity of sand required in such a case is large.

\section{ACKNOWLEDGEMENTS}

The author gratefully acknowledgments the Reseach unit for mineral processing Indonesian Institute of Sciences who have supported this research both in terms of finance and laboratory equipment.

\section{REFERENCES}

1. Widodo R. Forum Teknik Pengecoran Logam: Komunitas Praktisi Pengecoran Logam Indonesia. Available at: https://hapli.wordpress.com/foundry/pasir -cetak/ accessed August 2016.

2. S T Mihira. Small-Scale Metal Casting Industry in Indonesia: Situation and Problems. Asian Cultural Studies, 1998, III-A(8): 71-87

3. B Y L Shuaib, S S Yaru, S Abdulkareem, $S$ Ajayi, $Y$ O Busari, K S Ajao, H K Ibrahim, I O Ambali and G A Moahammed. Suitability of some selected Ado-Ekiti (Nigeria) natural Moulding Sands' Properties for sand casting. Covenant Journal of Engineering Technology (CJET). 2017, 1, 2, 53-64.

4. Sulistyani, E Priyambodo and L Yogantari. Mineral Content Analysis Of Merapi Volcanic Sand And Its Potential Application. Proceeding of International Conference On Research, Implementation And Education Of Mathematics And Sciences 2015, Yogyakarta State University.

5. P Puspitasari, Tuwoso and E Aristiyanto. Pengaruh Penggunaan Pasir Gunung Terhadap Kualitas dan Fluiditas Hasil Pengecoran Logam Paduan Al - Si. Jurnal Teknik Mesin. 2015, 24, 2, 21-27.

6. Yusup Hendronursito and Yogi Prayanda. Potensi Pasir Lokal Tanjung Bintang Pada Aluminium Sand Casting Terhadap Porositas Produk Hasil Cor Aluminium. Dinamika Teknik Mesin. 2016, 6,1, 70-75. 
7. A O Oke and B V Omidiji. Investigation of Some Moulding Properties of a Nigerian Clay-Bonded Sand. Archives Of Foundry Engineering. 2016, 16, 3, 71-76.

8. O Olasupo and $J$ A Omotoyinbo. Moulding Properties of a Nigerian Silica Clay Mixture For Foundry Use. Applied Clay Science. 2009. DOI: 10.1016/j.clay.2009.05.001

9. N A Ademoh and A T Abdullahi. Assessment of Foundry Properties of Steel Casting Moulds Bonded with Grade 4 Acacia Species (Gum arabic). International Journal of Physical sciences. 2009, 6, 238-241.

10. P N Rao. Manufacturing Technology Foundry, Forming and Welding. Tata McGraw- Hill. 2ndEdition. New Delhi, India, 2001.
11. $R \quad L$ Agarwal, $T R$ Banga and $T$ Nanghnani. Foundry Engineering. New Delhi: Khanna Publisher India. 1981.

12. A Turkeli. Sand, Sand Additives, Sand Properties, And Sand Reclamation. Foundry Technology. Available at: http://mimoza.marmara.edu.tr/ altan.turk eli/files/cpt-2-sand_sand.pdf. Accessed July 2017.

13. D R Askeland and W J Wright. The Science And Engineering Of Materials. Cengage Learning. $7^{\text {th }}$ ed. Boston, USA, 2015, p. 122-561.

14. $\mathrm{P} \quad \mathrm{L}$ Jain. Principles of Foundry Technology. Tata McGraw-Hill Publishing Company Limited. $4^{\text {th }}$ edition. New Delhi. 2003. 